\title{
COMPARATIVE STUDY OF THE CYTOTOXICITY AND APOPTOTIC EFFECT OF BEET ROOT, AND SILICA-BEET NANOPARTICLES WITH 5-FU NANOPARTICLES AGAINST SCC-090 CELL LINE
}

\author{
Shaimaa Omar Zayed*, Reham S. Hamed** and Usama Abd El Rouf El Dakrory****
}

\begin{abstract}
Objective: Nanoparticle delivery systems can be used to target anticancer drugs to tumor tissues. Beet root appears to be a powerful dietary source of antioxidant agent with anti-cancer effect due to ability to scavenge free radicals. Application of silica-nanoparticles (SiNP) in cancer treatment are promising, with increased data suggesting anti-proliferative effects in cancer cells. The aim of our study was to compare the cytotoxic effect of the beet root NP, silica-beet NP with 5 fu (flourarcil) NP, a chemotherapeutic agent against tongue carcinoma cell line scc-090.
\end{abstract}

Methods: Cell Line cells were obtained from American Type Culture Collection , cells were cultured using DMEM (Invitrogen/Life Technologies). Beet root nanoparticles Si-beet NP and 5FU drug NP were used. The effect of the tested materials were investigated by MTTassay and DNA fragmentation (DPA method).

Results: The MTT cytotoxicity assay revealed that beat root (nano) and Si-beat roots (nano) have obbvious cytotoxicity on SSC-090 cancer cell lines at low significant IC50 value as $0.73 \mu \mathrm{g} /$ $\mathrm{ml}$ and $2.94 \mu \mathrm{g} / \mathrm{ml}$ respectively. While 5FU drug revealed obvious cytotoxicity on SSC-090 cancer cell lines at higher value IC50 $8.83 \mathrm{ug} / \mathrm{ml}$. these results denote that low doses of beat root (nano) may exert remarkable cell death on tongue cancer cells line scc-090.

Conclusion: Our findings demonstrate that beet root NP could be capable of inducing cancer cell death with prominent apoptosis at very low ic 50 value $0.73 \mu \mathrm{g} / \mathrm{ml}$ against oral tongue carcinoma SCC-090 cell lines.

KEYWORDS: Beet root, silica nanoparticles, 5-FU drug and Apoptosis.

\section{INTRODUCTION}

Nanoparticle delivery concept can be used to target anticancer drugs to tumor tissues by either passive or active targeting. Passive targeting refers to the accumulation of a drug or drug carrier system at a desired depending on the inherent size of the nanoparticles, while, active targeting involves the attachment of a moiety, like a monoclonal antibody

* Lecturer, Oral Pathology Department, Faculty of Oral and Dental Medicine, Cairo University

** Lecturer, Oral surgery Department, Faculty of Oral surgey, Misr University for science and technology. 
or a ligand, to deliver a drug to pathological sites or to cross biological barriers based on molecular recognition processes ${ }^{[1]}$

The antioxidant, anti-inflammatory and vascular-protective effects offered by beetroot and its constituents have been investigated by several in vitro and in vivo human and animal studies; hence it might be considered for treatment of several pathological disorders ${ }^{[2]}$.

Red beet (Beta vulgaris var. rubra L., BVr) and green beet (B. vulgaris var. cicla L., BVc) belong to the same plant family (AmaranthaceaeChenopodiaceae). Beta vulgaris var. rubra L. is valued for its root, while $\mathrm{BVc}$ is grown for its leaves. The most important bioactive phytochemicals in $\mathrm{BVr}$ are betalains, pigments derived from betalamic acid and grouped into yellow betaxanthins (BX) and red betacyanins $(\mathrm{BC})$ with its powerful antioxidant and anti-inflammatory effect ${ }^{[3]}$.

Human diseases such as cancer, could result from oxidative stress produced by continual and excess production of reactive oxygen and nitrogen species (RONS) that induce long-term cellular disruption [4]. Therefore many antioxidant food sources have been evaluated for their ability to scavenge RONS and prevent oxidative stress ${ }^{[5]}$.

In a study conducted by Wootton-Beard, P.C. et $\mathrm{al}, 2011$, they found that found the betanin, the most abundant betalain found in beetroot was the most effective inhibitor of lipid peroxidation. Betanin has high antioxidant activity from its strong electron donating capacity and ability to defuse highly reactive radicals targeting cell membranes. They concluded that the main mechanism that beet root juice exerts its antioxidant effects is by scavenging free radical species ${ }^{[6]}$.

5-FU is an analogue of uracil with a fluorine atom at the C-5 position in place of hydrogen. It rapidly enters the cell. 5-FU is converted intracellularly to several active metabolites: fluorodeoxyuridine monophosphate (FdUMP), fluorodeoxyuridine triphosphate (FdUTP) and fluorouridine triphosphate (FUTP). These active metabolites disrupt RNA synthesis and the action of thymidylate synthase (TS) ${ }^{[7]}$.

More than $80 \%$ of administered 5-FU is normally catabolized primarily in the liver, where dihydropyrimidine dehydrogenase (DPD) is abundantly expressed causing unwanted side effects such as gastrointestinal symptoms, alopecia, cardiotoxicity, neutropenia, dermatitis, cardiac toxicity, and damage of the central nervous system result in limiting its applications ${ }^{[8,9]}$.

Application of silica-nanoparticles (SiNP) in cancer treatment are promising, with increased data suggesting anti-proliferative effects in cancer cells compared to normal cells. SiNPs present favorable characteristics, including wide bio-distribution, chemical stability, cellular internalization, and tumor penetration ${ }^{[10]}$.

In addition, studies report that SiNPs can trigger cytotoxic and genotoxic effects, causing generation of ROS, aberrant aggregation of nucleoplasmic proteins, DNA damage, and finally apoptotic death in treated cells. ${ }^{[1]}$.

Far to our knowledge, no studies were performed on the cytotoxic nanoparticle effect of beet root against cancer cells, so the aim of the present study was to compare the cytotoxic effect of the red beet root nanoparticles (NPs), silica-beet NPs with $5 f u$ (flourarcil ) NPs, a widely used chemotherapeutic agent against tongue carcinoma cell line scc-090.

\section{MATERIALS AND METHODS}

Cell Line Scc-090 (human tongue squamous cell carcinoma). cells were obtained from American Type Culture Collection, cells were cultured using DMEM (Invitrogen/Life Technologies) supplemented with 10\% FBS (Hyclone,), $10 \mathrm{ug} / \mathrm{ml}$ of insulin (Sigma), and 1\% penicillin-streptomycin. 
All of the other chemicals and reagents were from Sigma, or Invitrogen.

Cell culture protocol was done according to standard procedures at confirmatory diagnostic unit, VACSERA-Egypt. Plate cells (cells density $1.2-1.8$ $\times 10,000$ cells/well) in a volume of $100 \mu 1$ complete growth medium $+100 \mathrm{ul}$ of the tested compound per well in a 96-well plate for 24 hours before the MTT assay .

The cultures were incubated at $37^{\circ} \mathrm{C}$ for 24 hrs. After treatment of SCC-090 cells with the serial concentrations of the beet NPs, Si-beet NPs and 5FU NPs drug (100, 25, 6.25, 1.56 and $0.39 \mathrm{ug} / \mathrm{ml}$ ). Incubation is carried out for $48 \mathrm{~h}$ at $37^{\circ} \mathrm{C}$, then the plates are to be examined under the inverted microscope and proceed for the MTT assay.

\section{Nanoparticles preparation:}

Beet root, Si-beet and 5FU nanoparticles were prepared at National research center, Egypt. The plant extract was used to develop nano-suspension with poly acrylic acid (PAA) and calcium chloride. PAA solution was used at a concentration of $0.05 \%$ (in water) with $\mathrm{NaOH}$ to $\mathrm{pH} 8$ and $0.1 \%$ calcium chloride solution in water. In addition to silica -beet nano-suspention ${ }^{[12]}$.

The stability of nanoparticles were observed for 5 days in term of color, turbidity and sediment. Evaluation of nanoparticle included particles size (400-500 nm) using a Malvern Particle sizer and examination of the zeta potential using a Malvern zeta potential measuring device. ${ }^{[13]}$.

\section{Fluorouracil Encapsulated Chitosan Nanopar- ticles preparation}

Chitosan, derived from crab shell, in the form of flakes was purchased from Sigma-Aldrich (Medium Molecular Weight, Catalogue no. 448877).

The degree of deacetylation and molecular weight for the medium-molecular-weight chitosan (MWM chitosan) is $75-85 \%$ and $190-310 \mathrm{kDa}$ based on viscosity, respectively. ${ }^{[14]}$
Sodium tripolyphosphate (TPP) (purity: 85\%), 5-fluorouracil (5-FU) (purity: 99\%), and phosphate-buffered saline (PBS) tablets ( $\mathrm{pH} 7.4)$, were maintain chitosan concentration at $0.75(\mathrm{mg} /$ $\mathrm{mL}$ ). Prepared chitosan solutions were mixed with 5-FU solutions (5-FU dissolved in water), and $1.0 \mathrm{mg} / \mathrm{mL} 5-\mathrm{FU}$ containing chitosan solutions were maintained. Tween 80 (Sigma,Germany) (0.5\% $(\mathrm{v} / \mathrm{v}))$ was added to chitosan solutions, and $\mathrm{pH}$ was arranged as 4.6-4.8. Prepared 5-FU-containing chitosan solutions were flushed mixed with $0.5 \mathrm{mg} / \mathrm{mL}$ TPP solutions with a ratio of volume ratio of $(2: 1)(\mathrm{v} / \mathrm{v})$ (chitosan : TPP). The nanoparticle suspension was gently stirred for $20 \mathrm{~min}$ at room temperature to allow excess 5-FU adsorption on the nanoparticles to reach isothermal equilibrium. 5-FU encapsulated chitosan nanoparticles were centrifuged at $12000 \mathrm{~g}$ for $30 \mathrm{~min}$, re-suspended in water and freeze-dried used for further analyses. Prepared 5-FU encapsulated chitosan nanoparticles were analyzed by Zetasizer Nano S (Malvern,UK) in order to determine mean average particle size distributions. ${ }^{[15]}$

All nanoparticle solutions used for the current study were freshly prepared and sonicated before treatment at confirmatory diagnostic unit, VACSERA-Egypt. Nanoparticles were sterilized with UV exposure prior to the treatment

\section{Cytotoxicity assay protocol (MTT)}

The MTT method of monitoring in vitro cytotoxicity is a mean to measure the activity of living cells by mitochondrial dehydrogenases. The key component is (3-[4,5dimethylthiazol-2yl]-2,5-diphenyl tetrazolium bromide) or MTT. Solutions of MTT, dissolved in medium or balanced salt solutions without phenol red, are yellowish in color. Mitochondrial dehydrogenases of viable cells cleave the tetrazolium ring, yielding purple formazan crystals which are insoluble in aqueous solutions. ${ }^{[16]}$ 
The crystals are dissolved in acidified isopropanol. The resulting purple solution is spectrophotometrically measured. ${ }^{[17]}$. An increase or decrease in cell number results in a concomitant change in the amount of formazan formed, indicating the degree of cytotoxicity caused by the test material using BIOLINE ELIZA READER. IN VITRO TOXICOLOGY ASSAY KIT MTT BASED Stock No. TOX-1. 7H258, Sigma-Aldrich, Inc. the MTT assay was done according to the standard procedure at confirmatory diagnostic unit, VACSERA-Egypt. Spectrophotometrically measure absorbance at a wavelength of $570 \mathrm{~nm}$ for spectrophotometric measurement using BIOLINE ELIZA READER.

\section{DNA fragmentation assay [Diphenylamine (DPA) method]}

This method is based on that extensively fragmented double-stranded DNA can be separated from chromosomic DNA upon centrifugal sedimentation. The protocol includes the lysis of cells and the release of nuclear DNA, a centrifugation step with the generation of two fractions (corresponding to intact and fragmented DNA, respectively), precipitation of DNA, hydrolysis and colorimetrical quantitation upon staining with diphenylamine (DPA), which binds to deoxyribose ${ }^{[18,19]}$.

The Kit used for enzyme-assay: SIGMA chemical using BIOLINE ELIZA READER wl 450nm Solvent DMSO following the standard procedure at confirmatory diagnostic unit, VACSERA-Egypt.

\section{Measurement of growth by the diphenylamine colorimetric method}

Diphenylamine reagent (Burton 1956) for colorimetric assay was prepared by dissolving $1.5 \mathrm{~g}$ of reagent-grade diphenylamine in $100 \mathrm{ml}$ of glacial acetic acid and then adding $1.5 \mathrm{ml}$ concentrated $\mathrm{H} 2 \mathrm{SO} 4$. Prior to use, $1.6 \%$ of aqueous acetaldehyde was added to $100 \mathrm{ml}$ of diphenylamine reagent. It is notable that the agent must be colorless and stored in the dark. For growth quantification by the diphenylamine colorimetric reaction, cell pellets were harvested from $1 \mathrm{ml}$ cultures by centrifugation at $10,000 \times \mathrm{g}$ for $10 \mathrm{~min}$ and then washed twice with appropriate buffer. Then, the cell pellets were resuspended with $2 \mathrm{ml}$ diphenylamine reagent and incubated at $60{ }^{\circ} \mathrm{C}$ for $1 \mathrm{~h}$. The supernatants from the diphenylamine reactions were collected after centrifugation and transferred to 96-well micro titer plates measured by a multi-functional microtiter plate reader (Synergy Hybrid Reader, BioTek, USA). The readings measured by this reaction system are all within the standard error of the optical density measurement. ${ }^{[20]}$.

\section{RESULTS}

\section{MTT cytotoxicity assay}

The MTT cytotoxicity assay revealed that beet root NP and Si-beet root NP have obvious cytotoxicity on SSC-090 cancer cell lines at low significant IC50 value as $0.73 \mu \mathrm{g} / \mathrm{ml}$ and $2.94 \mu \mathrm{g} /$ $\mathrm{ml}$ respectively after incubation period 48 hours. While 5FU drug revealed obvious cytotoxicity on SSC-090 cancer cell lines at higher value IC50 8.83 $\mu \mathrm{g} / \mathrm{ml}$ after incubation period 48 hours table $(1,2)$ (fig. 1,2). These results denote that low doses of beet root NP may exert remarkable cell death on tongue cancer cells line scc-090.

Combining Si-beet NP revealed obvious cytotoxic effect on cancer cells but at a higher significant IC50 value $2.93 \mu \mathrm{g} / \mathrm{ml}$. While beet NP without silica, produced obvious cytotoxic effect on cancer cells at very lower significant IC5 value $0.73 \mu \mathrm{g} / \mathrm{ml}$. this may denote that addition of silica did not enhance the cytotoxic effect of beet root NP. (fig. 1,2)

\section{DNA fragmentation assay}

Our results showed that Beet root nanoparticles when added to tongue cancer cell line ssc-090 revealed a highly significant DNA fragmentation of cancerous cells in comparison to non- treated 
TABLE (1) Showing the comparison of IC50 values of the beet NP, si-beet NP and $5 f u$ NP drug against tongue carcinoma cell line (scc-090) ANOVA t-test.

\begin{tabular}{|c|l|l|}
\hline \multirow{2}{*}{ Ser } & \multirow{2}{*}{ Sample code } & IC50-uM \\
\cline { 3 - 3 } & & UPCI:SCC090 \\
\hline 1 & Beet Roots NPs & $0.73 \pm 0.02$ \\
\hline 2 & Si-Beet NPs & $2.94 \pm 0.12$ \\
\hline 3 & 5FU NPS & $8.83 \pm 0.51$ \\
\hline & p-value & 0.000 \\
\hline
\end{tabular}

TABLE (2). Showing highly significant difference between control untreated cancer cells and the treated cancer cells with either beet NP, Si-beet NP and 5FU NP drug ANOVA test.

\begin{tabular}{|c|c|c|c|c|c|}
\hline Groups & Control & Beet NP & Si-beet NP & $\begin{array}{c}5 F U \\
\text { NP }\end{array}$ & $\begin{array}{c}\text { p-value } \\
\text { (ANOVA) }\end{array}$ \\
\hline Mean \pm SD & $0.44167 \pm 8.643 \mathrm{E}-03$ & $0.191667 \pm 4.506 \mathrm{E}-03$ & $0.241667 \pm 3.507 \mathrm{E}-03$ & $0.255 \pm 4.025 \mathrm{E}-03$ & 0.000 \\
\hline
\end{tabular}

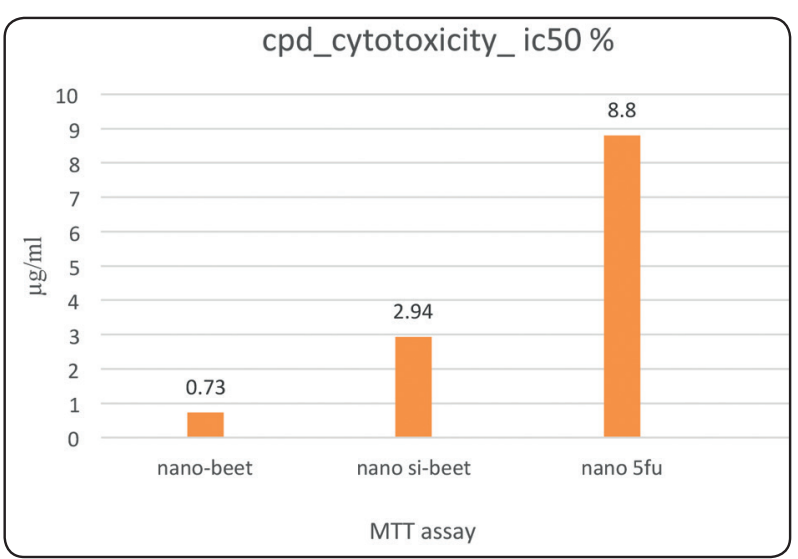

Fig. (1): Bar chart showing comparison of cytotoxicity-ic50 value of beet root NP Si-beet NP and 5fu NP drug against tongue carcinoma cell line (scc-090). Notice that beet root NP produced the cytotoxic effect on cancer cells at very low significant value of ic50 $0.73 \mu \mathrm{g} / \mathrm{ml}$ denoting the strong cytotoxic effect of this plant.

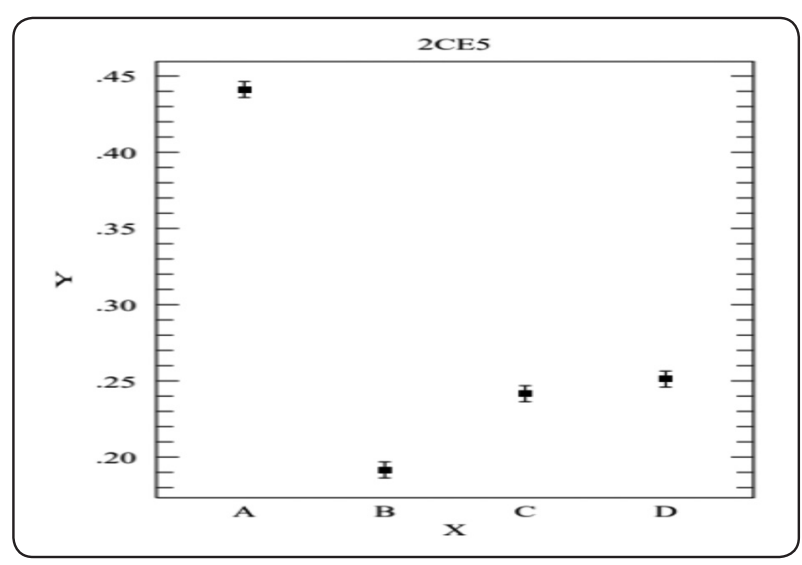

Fig. (2) Pot graph showing the cytotoxic effect of beet NP (B), Si-beet NP (C) and 5FU NP (D) on cancer cell viability in comparison to control non-treated cancer cells scc-090 (A). ANOVA test with plot output variance. Notice that the viability of scc-090 cancer cells highly decreased when treated by beet NP (B) 


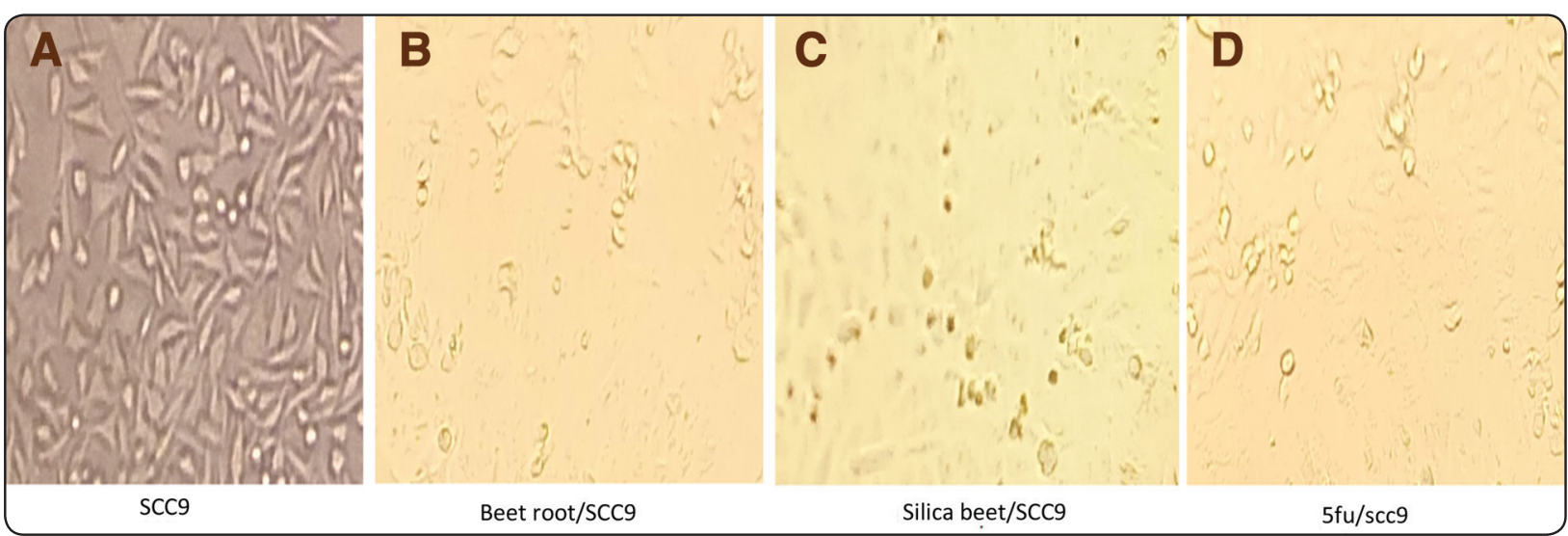

Fig. (3) A- SCC-090 cell line before treatment, beet NP against scc090. C-Si-beet NP against scc090. D-5fu NP against scc090. After $48 \mathrm{hs}$ incubation period. cell culture images by inverted microscope.

cancer cells denoting the strong apoptotic effect of nano-beet particles. While, the si-beet nanoparticles revealed lower value of DNA fragmentation of scc090 cells compared to nano-beet group. However, si-beet nanoparticles produced also a highly significant apoptotic effect in comparison to nontreated cancer cells table (3) fig (4).

TABLE (3) Showing highly significant difference between control untreated cancer cells SCC-090 and the treated cancer cells with the nano-beet, silica loaded nano-particle and 5FU-nano in reference to DNA fragmentation ANOVA test.

\begin{tabular}{|c|l|l|}
\hline \multirow{2}{*}{ S r } & \multirow{2}{*}{ Sample code } & DPA \\
\cline { 3 - 3 } & & UPCI:SCC090 \\
\cline { 3 - 3 } & & \% DNA fragmentation \\
\hline 1 & Beet Root NPs & 60.88496 \\
\hline 2 & Si-Beet NPs & 39.87539 \\
\hline 3 & 5FU NPs & 45.22145 \\
\hline 4 & Control SCC090 & 9.965035 \\
\hline & p-value & 0.000 \\
\hline
\end{tabular}

Moreover, 5fu nanoparticles revealed a highly significant DNA fragmentation $45 \%$ of cancerous scc-090 cell line in comparison to non- treated cancer cells denoting the strong apoptotic effect of nano-5fu particles. Our previous observations may reveal that nano-beet particles have the highest DNA fragmentation and so strong apoptosis of cancer cells scc-090 table (3) fig. (4).

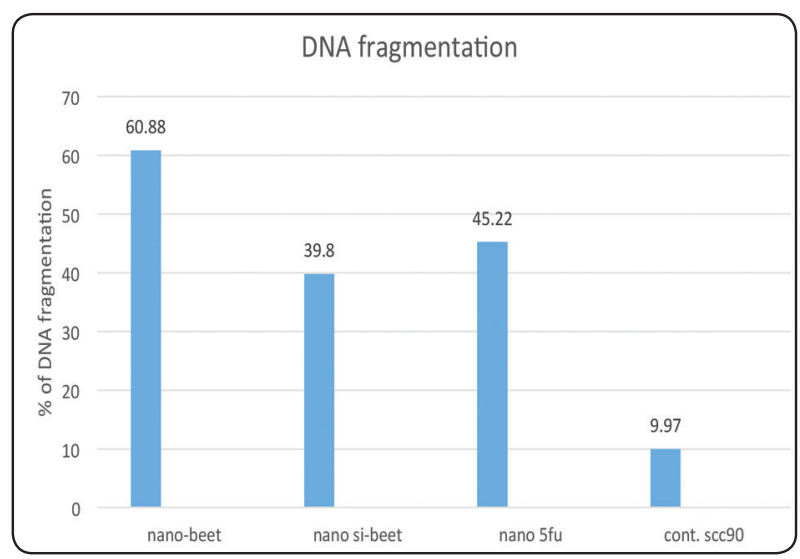

Fig. (4) bar chart showing the prominent apoptotic effect of beet root NPs, si- beet NPs and 5FU NPs drug against SCC-090 tongue cancer cell lines. Notice that the highest value apoptosis was revealed by beet root NP. 


\section{DISCUSSION}

For cancer therapy using nanotechnology, the nano-therapeutic agents are supposed to be released into the interstitial fluid, tumor surface or directly into the intracellular space. Where, endocytosis needs to occur from plasma membrane to the cytosol as well as lysosomes, where the particles degrade and release their payloads ${ }^{[21]}$.

In the present study, the MTT cytotoxicity assay revealed that beet root $n p$ and Si-beet NP have obvious cytotoxicity on SSC-090 cancer cell lines at low significant IC50 as $0.73 \mu \mathrm{g} / \mathrm{ml}$ and $2.94 \mu \mathrm{g} / \mathrm{ml}$ respectively $48 \mathrm{hrs}$ compared to non-treated cancer cells after incubation period 48 hours. Moreover, 5FU NP drug revealed obvious cytotoxicity on SSC-090 cancer cell lines at higher significant value IC50 $8.83 \mu \mathrm{g} / \mathrm{ml}$ after incubation period $48 \mathrm{hrs}$ compared to beet NP and Si-beet NP treated cancer scc-090 cells

The previous observation may denote that very low doses of nano-beet may have a prominent cytotoxic effect on tongue cancer cells (scc-090) and consider beet root plant as pharmaceutical active agent since the US Food and Drug Administration (FDA) and national cancer institute USA, considered that plant extract with IC50 values $\leq$ $20 \mu \mathrm{g} / \mathrm{ml}$ following incubation between 48 and $72 \mathrm{~h}$, are considered pharmaceutically effective agent and can be used as bench mark for suitable screening cancer drugs from plants and herbs. ${ }^{[22]}$.

The previous observation in accordance with Paluszczak, J et al, 2010. They showed that the beet root extract, betaine may act as a cytotoxic agent by methylating DNA in cancer cells. They explained that betanin could inhibit the DNA methyltransferase activity in human breast cancer MCF-7 cells ${ }^{[23]}$

A study conducted by Govind J. Kapadia1, they used two cancer cell lines of human origin (prostate PC-3 and breast MCF-7), the beetroot extract was shown to exhibit consistent cytotoxic activity. ${ }^{[24]}$
An interesting observation in our study that combining of silica NP to beet root NP revealed obvious cytotoxic effect on cancer cells but at higher significant iC50 value $2.93 \mu \mathrm{g} / \mathrm{ml}$ after incubation period $48 \mathrm{hrs}$. While beet root NP without silica, produced obvious cytotoxic effect on cancer cells at very low significant IC50 value $0.73 \mu \mathrm{g} / \mathrm{ml}$. this may denote that addition of silica did not enhance the cytotoxic effect of beet root NP.

The previous observation could be explained on the basis that molecular cell response to NP treatment are strictly dependent on the cellular uptake of these particles. It was found that SiNPs can easily enter cells by endocytosis, localizing to the cytoplasm or cellular organelles, such as the endoplasmic reticulum (ER) and mitochondria. ${ }^{[25]}$

Meanwhile, NP size is an important factor influencing NP-dependent cellular effects. Lu et al showed that decreasing NP size $(7-20 \mathrm{~nm})$ increased their diffusivity intracellular, while other studies have suggested that the size of inorganic NPs (100 $\mathrm{nm}$ or $70 \mathrm{~nm}$ ) accumulate at the tumor site with different degree of intracellular diffusion. ${ }^{[26]}$

In the current study, the growth inhibitory effect and apoptosis of both Beet root NP and Si-beet NP were evident in the two groups on cancer cells line scc-090 but the beet root NP revealed significant higher apoptotic effect at lower significant IC50 value.

The previous observation in accordance with Farabegoli F, et al, 2017. They found that cytotoxicity of BX and BC (beet root active metabolites) showed a high cytotoxicity at ic50 $0.25-0.35 \mu \mathrm{g} / \mathrm{mL}$ against CaCo-2 colorectal cancer cells. They found the cytotoxic effect was exerted through the activation of apoptosis ${ }^{[27]}$

In a study conducted by $\mathrm{Lu}$ et al, when using SiNP treatment, they found increased expression of p53 and caspase 3 and decreased expression of $\mathrm{Bcl} 2$ and procaspase 9 in human HEPG2 hepatoma cells, 
while none of these effects were observed in normal human L02 hepatocytes ${ }^{[28]}$.

Scarpa etal.,2017 examined the anti-proliferative effect vitexin-2-O-xyloside a major conistituent of green beet against $\mathrm{CaCo}-2$ colon cancer cells and HepG2 liver cancer cells, 30- $\mu \mathrm{M}$ vitexin-2-Oxyloside was able to induce a remarkable increase in the endogenous ROS levels, in both $\mathrm{CaCo}-2$ and HepG2 cancer cells, leading to the reduction of their proliferation rate[29]. Harris and Brugge, 2015 concluded that vitexin-2-O-xyloside could act as a pro-oxidant when it enters cancer cells in certain concentrations, and it may kill the cancer cell by exacerbating oxidative stress and interfering with cell signaling pathways at different levels. ${ }^{[30]}$.

Farabegoli et al., 2017 found that, BX and $\mathrm{BC}$ were able to reduce oxidative damage caused directly by $\mathrm{H} 2 \mathrm{O} 2$ in $\mathrm{CaCo}-2$ colon cancer cells. They concluded that betalains exert their antioxidant effect at a genomic level by increasing the expression and transcriptional activity of the redox-sensitive transcription factor nuclear factor (erythroid-derived 2)-like 2 (Nrf2) (Na and Surh, 2014), which is normally bound to the cytosolic protein Kelch-like ECHassociated protein 1 $(\text { Keap } 1)^{[31]}$. When betalains react with the redoxreactive cysteine residues of Keap1, the connection Nrf2-Keap1 is disrupted and Nrf2 translocates into the nucleus, where it binds to the antioxidant responsive elements and initiates the gene transcription of phase-II and antioxidant enzymes so batalin behave as antioxidants in both human erythrocytes and cancer cells ${ }^{[32,33]}$.

An animal study conducted by Lechener et al, 2010. They investigated if long term (35 weeks) treatment with a betacyanin containing extract (78 $\mu \mathrm{g}$-mL-day-1 of E162, red food colour prepared from beetroot) would inhibit tumour incidence in rats exposed to a potent tumour promoter (N-nitrosomethylbenzylamine). In comparison to control, the beetroot extracts markedly inhibited cell proliferation, angiogenesis and tumorgenesis in oesophageal lesions. They revealed that beet root effect could be attributed to its radical scavenging and anti-inflammatory activity. ${ }^{[34]}$.

Another animal study presented by Szaefer, $\mathrm{H}$ et al, 2014, where the experimental rats were fed beetroot juice ( $8 \mathrm{~mL}-\mathrm{kg}$-bm-day-1 for 28 days) and treated with the carcinogen 7,12-dimethylbenz[a] anthracene (DMBA). On day 27 and 28 of the beetroot juice-feeding period study. Markers of liver damage and inflammation were significantly increased following the DMBA treatment; however, these were markedly reduced in the rats pretreated with beetroot juice compared to the control group that received water only. They explained the results that beetroot extracts appeared to maintain endogenous antioxidant activity (reduced glutathione, glutathione peroxidase and catalase enzymes) at normal cellular concentrations following the oxidative insult, beetroot may exhibit indirect antioxidant effects that act to up regulate antioxidant defence mechanisms. ${ }^{[35]}$.

In the current study, the DNA fragmentation assay revealed that Beet root NP when added to tongue cancer cell line ssc-090 showed a highly significant DNA fragmentation of cancerous cells in comparison to non- treated cancer cells denoting the strong apoptotic effect of nano-beet particles. While, the si-beet NP revealed lower value of DNA fragmentation of scc-090 cells compared to beet NP group. However, si-beet nanoparticles produced also a highly significant apoptotic effect in comparison to non- treated cancer cells.

In addition, our study revealed that $5 \mathrm{fu}$ nanoparticles revealed a highly significant DNA fragmentation of cancerous scc-090 cell line in comparison to non- treated cancer cells denoting the strong apoptotic effect of nano-5fu particles. Our previous observations may reveal that beet NPs have the highest DNA fragmentation and so higher apoptotic effect against tongue cancer cell line scc-090. 
The previous findings are in accordance with a study conducted by Nowacki et al., 2015. They investigated the antiproliferative effect of beet root bioactive $\mathrm{BC}$ agent in MCF-7 breast cancer cells, they showed that a mixture of betanin/isobetanin is able to induce apoptosis in these cancer cells, through the activation of $\mathrm{p} 53$, increase of the protein levels of pro-apoptotic factors Bcl-2-associated death promoter (Bad), TNF-related apoptosisinducing ligand receptor 4 (TRAILR4), Fas and so induction of autophagic cell death ${ }^{[36]}$.

The anti-apoptotic effect of $5 f u$ anti -cancer drug was revealed by DNA microarray screen of 5-FU-inducible target genes was FAS. ${ }^{[37]}$. FAS is a member of the tumour necrosis factor (TNF) receptor superfamily, which, when bound by its cognate ligand FASL, recruits caspase- 8 zymogens via the adaptor protein FADD (FAS-associated death domain). The FASL/FAS/FADD/caspase-8 complex is known as the death-inducing signalling complex (DISC). Caspase- 8 is activated at the DISC and subsequently initiates a caspase cascade that results in apoptosis ${ }^{[38]}$. We could conclude that beet root and 5 fu drug have similar apoptotic effect on cancer cells by activation of FAS pathway

The chemotherapeutic agents, daunorubicin and its analogs, doxorubicin, epirubicin and idarubicin. ${ }^{[39]}$. appear to exert their lethal effects on cancer cells via intercalation with DNA bases. ${ }^{[40]}$, and by inhibition of DNA topoisomerase I and II enzyme activities. ${ }^{[41]}$ An interesting observation conducted by the betanin red beetroot extract, there is a striking similarity in the chemical structure and configuration with the anticancer compounds, e.g., doxorubicin, both have a planar aromatic chromophore and a six-membered sugar molecule which produce intercalation with DNA in cancer cells causing cancer cell death ${ }^{[42]}$. This suggests that betanin may play a major role in the observed cytotoxic effect of the red beetroot extract through a possible mechanism of action common with doxorubicin and related anthracycline chemotherapeutic drugs. ${ }^{[43]}$

\section{CONCLUSION}

The beet root and silica -beet nanoparticle might be capable of inducing cancer cell death against SCC-090 cell lines by induction of apoptosis.

\section{RECOMMENDATION}

Further studies should be performed to investigate the beet root effect on molecular level of cell pathways and it should be screened against more cancer cell lines for the possible use of this plant for chemotherapy in the future.

\section{Compliance with ethical standards}

Conflicts of interest. The authors declare that they have no conflict of interest.

\section{REFERENCES}

1. Wang X, Yang L, Chen ZG, Shin DM. Application of nanotechnology in cancer therapy and imaging. CA Cancer J Clin 2008; 58:97-110; PMID:18227410; http:// dx.doi.org/10.3322/CA.2007.0003

2. Vulić, J.J.; Ćebović, T.N.; Čanadanović-Brunet, J.M.; Ćetković, G.S.; Čanadanović, V.M.; Djilas, S.M.; Tumbas Šaponjac, V.T. In vivo and in vitro antioxidant effects of beetroot pomace extracts. J. Funct. Foods 2014, 6, 168-175

3. Ninfali P, Angelino D. 2013. Nutritional and functional potential of Beta vulgaris cicla and rubra. Fitoterapia 89: 188-199.

4. Lobo, V.; Patil, A.; Phatak, A.; Chandra, N. Free radicals, antioxidants and functional foods: Impact on human health. Pharmacol. Rev. 2010, 4, 118-126.

5. Tesoriere, L.; Fazzari, M.; Angileri, F.; Gentile, C.; Livrea, M.A. In vitro digestion of betalainic foods. Stability and bioaccessibility of betaxanthins and betacyanins and antioxidative potential of food digesta. J. Agric. Food. Chem. 2008, 56, 10487-10492.

6. Wootton-Beard, P.C.; Moran, A.; Ryan, L. Stability of the total antioxidant capacity and total polyphenol content of 23 commercially available vegetable juices before and after in vitro digestion measured by FRAP, DPPH, ABTS and Folin-Ciocalteu methods. Food. Res. Int. 2011, 44, 217-224. 
7. Wohlhueter, R. M., McIvor, R. S. \& Plagemann, P. G. Facilitated transport of uracil and 5-fluorouracil, and permeation of orotic acid into cultured mammalian cells. J. Cell Physiol. 104, 309-319 (1980).

8. Joag MG, Sise A, Murillo JC, Sayed-Ahmed IO, Wong JR, Mercado C et al. Topical 5-Fluorouracil 1\% as Primary Treatment for Ocular Surface Squamous Neoplasia. Ophthalmology 2016; 123: 1442-1448.

9. Kuropkat C, Griem K, Clark J, Rodriguez ER, Hutchinson $\mathrm{J}$, Taylor SG $4^{\text {th }}$ Am.Severe cardiotoxicity during 5-fluorouracil chemotherapy: a case and literature report. J Clin Oncol. 1999 Oct; 22(5):466-70.

10. Ahmad J,Ahamed M,Akhtar MJ, et al. Apoptosis induction by silica nanoparticles mediated through reactive oxygen species in human liver cell line HepG2. Toxicol Appl Pharmacol. 2012;259:160-168

11. Mu Q, Hondow NS, Krzemiński L, Brown AP, Jeuken LJ Routledge MN. Mechanism of cellular uptake of genotoxic silica nanoparticles. Part Fibre Toxicol. 2012;9:29

12. Ahmadkhani L, Baghban A, Mohammadpoor S, Khalilov R, Akbarzadeh A, Kavetskyy T, Saghfi S, Nasibova AN.: Synthesis and Evaluation of a Triblock Copolymer/ZnO Nanoparticles from Poly( $\varepsilon$-caprolactone) and Poly(Acrylic Acid) as a Potential Drug Delivery Carrier. Drug Res (Stuttg). Apr;67(4):228-238, 2017. doi: 10.1055/s-0042124190. Epub 2017 Feb 14.

13. Sachiko Kaihara Nitta and Keiji Numata BiopolymerBased Nanoparticles for Drug/Gene Delivery and Tissue Engineering. Int J Mol Sci. 2013 Jan; 14(1): 1629-1654.

14. Hou Y, Hu J, Park H, Lee M. Chitosanbased nanoparticles as a sustained protein release carrier for tissue engineering applications. Journal of Biomedical Materials Research Part A. 2012; 100A (4): 939947.

15. Shanmuga Sundar Saravanabhavan1, Rekha Bose2, Sridhar Skylab2, Sangeetha Dharmalingam.Fabrication of chitosan/TPP nanoparticles as a carrier towards the treatment of cancer. International Journal of Drug Delivery (2013) 5: 35-4

16. Denizot, F. and Lang, R. [1986] Rapid colorimetric assay for cell growth and survival. Modifications to the tetrazolium dye procedure giving improved sensitivity and reliability. J. Immunol. Methods 89:271 [15] .

17. Vistica, D. et al. [1991] Tetrazolium-based assays for cellular viability: a critical examination of selected parameters affecting formazan production. Cancer Research 51:2515-2520 [16].
18. Burton K (1956) A study of the conditions and mechanism of the diphenylamine reaction for the colorimetric estimation of deoxyribonucleic acid. Biochem J 62(2):315-323.

19. Lancker MV, Gheyssens LC (1986) A comparison of four frequently used assays for quantitative determination of DNA. Anal Lett 19(5-6):615-623.

20. Youbao Zhao \& Sihai Xiang \& Xida Dai \& Keqian Yan.: A simplified diphenylamine colorimetric method for growth quantification. Appl Microbiol Biotechnol (2013) 97:5069-5077.

21. Rosenholm JM, Sahlgren C, Lindén M. Towards multifunctional, targeted drug delivery systems using mesoporous silica nanoparticles-opportunities \& challenges. Nanoscale 2010; 2:1870-83; PMID :20730166; http://dx.doi. org/10.1039/c0nr00156b

22. Boik J. Natural Compounds in Cancer Therapy. Princeton, Minn, USA: Oregon Medical Press; 2001

23. Paluszczak, J.; Ktajka-Kuzniak, V.; Baer-Dubowska, W. The effect of dietary polyphenols on the epigenetic regulation of gene expression in MCF7 breast cancer cells. Toxicol. Lett., 2010, 192, 119-125

24. Govind J. Kapadia, Magnus A. Azuine, G. Subba Rao, Takanari Arai, Akira Iida and Harukuni Tokuda.: Cytotoxic Effect of the Red Beetroot (Beta vulgaris L.) Extract Compared to Doxorubicin (Adriamycin) in the Human Prostate (PC-3) and Breast (MCF-7) Cancer Cell Lines. Anti-Cancer Agents in Medicinal Chemistry, 2011, 11, 280-284.

25. Parveen A, Rizvi SHM, Mahdi F, et al. Silica nanoparticles mediated neuronal cell death in corpus striatum of rat brain: implication of mitochondrial, endoplasmic reticulum and oxidative stress. J Nanopart Res. 2014;16:2664.

26. Sarin H, Kanevsky AS, Wu HT, et al. Physiologic upper limit of pore size in the blood-tumor barrier of malignant solid tumors. J Transl Med. 2009;7:51.

27. Farabegoli F, Scarpa ES, Frati A, et al. 2017. Betalains increase vitexin-2-O-xyloside cytotoxicity in $\mathrm{CaCo}-2$ cancer cells. Food Chem 218: 356-364.

28. Lu X, Qian J, Zhou H, et al. In vitro cytotoxicity and induction of apoptosis by silica nanoparticles in human HepG2 hepatoma cells. Int J Nanomedicine. 2011;6:1889-18901.

29. Scarpa ES, Antonini E, Palma F, Mari M, Ninfali P. 2017. Antiproliferative activity of vitexin-2-O-xyloside and avenanthramides on CaCo-2 and HepG2 cancer cells occurs through apoptosis induction and reduction of pro-survival mechanisms. 
30. Harris IS, Brugge JS. 2015. Cancer: the enemy of my enemy is my friend. Nature 527: 170-171.

31. Farabegoli F, Scarpa ES, Frati A, et al. 2017. Betalains increase vitexin-2-O-xyloside cytotoxicity in $\mathrm{CaCo}-2$ cancer cells. Food Chem 218: 356-364.

32. Esatbeyoglu T, Wagner AE, Motafakkerazad R, Nakajima Y, Matsugo S, Rimbach G. 2014. Free radical scavenging and antioxidant activity of betanin: electron spin resonance spectroscopy studies and studies in cultured cells. Food Chem Toxicol 73: 119.

33. Krajka-Kuzniak V, Paluszczak J, Szaefer H, BaerDubowska W. 2013. Betanin, a beetroot component, induces nuclear factor erythroid-2-related factor 2-mediated expression of detoxifying/antioxidant enzymes in human liver cell lines. Brit J Nutr 110: 2138-2149.

34. Lechner, J.F.; Wang, L.S.; Rocha, C.M.; Larue, B.; Henry, C.; McIntyre, C.M.; Riedl, K.M.; Schwartz, S.J.; Stoner, G.D. Drinking water with red beetroot food color antagonizes esophageal carcinogenesis in N-nitrosomethylbenzylamine-treated rats. J. Med. Food 2010, 13, 733-739

35. Szaefer, H.; Krajka-Kuźniak, V.; Ignatowicz, E.; Adamska, T.; Baer-Dubowska, W. Evaluation of the effect of beetroot juice on DMBA-induced damage in liver and mammary gland of female Sprague-Dawley rats. Phytother. Res. 2014, 28, 55-61

36. Nowacki L, Vigneron P, Rotellini L, et al. 2015. Betaninenriched red beetroot (Beta vulgaris L.) extract induces apoptosis and autophagic cell death in MCF-7 cells. Phytother Res 29: 1964-1973
37. Nagata, S. Fas ligand-induced apoptosis. Annu. Rev. Genet. 33, 29-55 (1999).

38. Houghton, J. A., Harwood, F. G. \& Tillman, D. M. Thymineless death in colon carcinoma cells is mediated via fas signaling. Proc. Natl Acad. Sci. USA 94, 8144-8149. (1997)

39. Lown, J.W. Anthracycline and anthraquinone anticancer agents: Current status and recent developments. Pharmacol. Ther., 1993, 60, 185-214.

40. Formari, F.A.; Randolph, J.J.; Yalowich, J.C.; Ritke, M.K.; Gewirtz, D.A. Interference of doxorubicin with DNA unwinding in MCF-7 breast tumor cells. Mol. Pharmacol., 1994, 45, 649-656

41. Bodley, A.; Liu, L.F.; Israel, M.; Seshadri, R.; Koseki, Y.; Giuliani, F.C.; Kirschenbaum, S.; Silber, R.; Potmesil, M. DNA topoisomerase II-mediated interaction of doxorubicin and daunorubicin congeners with DNA. Cancer Res.. 1989, 49, 5969-5978.

42. Formari, F.A.; Randolph, J.J.; Yalowich, J.C.; Ritke, M.K.; Gewirtz, D.A. Interference of doxorubicin with DNA unwinding in MCF-7 breast tumor cells. Mol. Pharmacol., 1994, 45, 649-656 .

43. Govind J. Kapadia1, Magnus A. Azuine,2 G. Subba Rao,3 Takanari Arai,4 Akira Iida5 and Harukuni Tokuda. Cytotoxic Effect of the Red Beetroot (Beta vulgaris L.) Extract Compared to Doxorubicin (Adriamycin) in the Human Prostate (PC-3) and Breast (MCF-7) Cancer Cell Lines. Anti-Cancer Agents in Medicinal Chemistry, 2011, 11, 280-284. 